\title{
IMPROVING STUDENT (SANTRI) CARE FOR THE LIVING ENVIRONMENT IN NURUL HUDA ISLAMIC BOARDING SCHOOL, DEPOK
}

\author{
Sri Rahayu Pudjiastuti ${ }^{a *}$ \\ ${ }^{a)}$ STKIP Arrahmaniyah, Depok, Indonesia \\ ${ }^{*}$ Corresponding Author: yayu.pudjiastuti@gmail.com
}

Article history: received 15 January 2020; revised 09 February 2020; accepted 20 February 2020

\begin{abstract}
In general, santri (student) in islamic boarding school do not have clean habits. The habit that is actually throwing garbage in the river/sewer, someone else's yard, empty land, by burning it, or handing over garbage that has not been sorted out to the garbage officer/cleaning service. This study aims to provide an overview, analysis and recommendations (problem solving) about the need to strengthen environmental education (specifically about waste) to increase santri concern for the environment. This research method uses descriptive analysis method that is supported by secondary data and literature studies. The number of respondents 80 santri (santri). The results showed: environmental care programs can be realized well if supported by four basic elements namely; policies of environmentally friendly institutions, implementation of environment-based curriculum, participatory-based environmental activities, and management of environmentally friendly supporting facilities. The environmental care program is essentially the formation of attitudes and behaviors that are pro-environment, including waste management which applies the 3R principle (reuse, reduse, recycle) to reuse goods, reduce consumption on goods, and recycle items that are is not used anymore
\end{abstract}

Keywords: santri care; environment.

\section{INTRODUCTION}

Education is the most important factor and a top priority that requires serious attention from all parties, because education is a determinant of the nation's progress in the future [1]. National goals and ideals, for the intellectual life of the nation is contained in the 1945 Constitution. The government together with the community continues to seek the development of education for the realization of an independent, superior and ready nation to face the globalization world [2]. Education is a major factor in the formation of the human person. Therefore the education sector needs to be given serious attention because with a good education system it is expected that the next generation of quality, superior and competitive emerges [3].

The santri lack of concern for the cleanliness of the surrounding environment shows that they have not been able to implement the first precept of Pancasila. The values contained are belief and piety in God Almighty in accordance with their respective religions and beliefs on the basis of fair and civilized humanity. Based on these values, all religious people require their owners to clean themselves and the surrounding environment as evidence of people's faith and devotion to God Almighty [4]. The poor management of waste is also because there is a gap between knowledge and behavior that is revealed. Survey data shows that the knowledge of the population in terms of air pollution due to burning of waste is $80.57 \%$, but only about $43.10 \%$ of the population cares about waste [5].

Parenting is a habit that is usually done by fathers and mothers that are applied to children in their development [6]. santri concern for the environment is a real behavior towards the environment. The basis of behavior is attitude. That is, someone who has a positive attitude towards the environment, will show positive behavior. Vice versa, negative attitudes will accompany negative behavior [7]. The concern of santri is important because; (1) santri are future leaders. If from the beginning santri have been involved in environmental care activities and when they become leaders, environmental issues will become a priority in their work plans. (2) About $75 \%$ of children never sort trash, and they only litter [8]. This information is very worrying, because maybe their behavior will get worse later.

In order for santri to care for the trash around them, care must be fostered from an early age. This environmental care program is in accordance with social learning theory or Bandura's modeling theory, that children learn about proenvironment attitudes and behavior from models/ustadz/ ustazah (Islamic teacher) who have a strong influence. Through a process of observing and imitating consistent behavior, it is hoped that children will care for trash in their daily lives [9]. In the Islam boarding school environment, pro-environment behavior in santri is formed due to external factors or models in this case is the teacher. Children learn about managing waste wisely from observing the behavior of the ustadz/ustazah. The formation of pro-environment behavior occurs because the ustadz/ustazah has the authority to reward and punish. That authority must be carried out consistently. If the ustadz/ustazah is not consistent, then the child becomes confused or does not understand the importance of the concept of reward-punishment for the formation of behavior. Based on this theory, it is expected that someday when an adult is able to behave proenvironment without having to be watched by others. Suchyadi revealed that differences in the character of children with diverse needs will require the ability of teachers to combine the various abilities and talents of each child [10]. 
Likewise, the theory of behaviorism with figures Watson, Pavlov, Skinner and Thondike. This theory explains that human behavior is completely controlled by external factors namely the environment. This theory has two principles; first, human behavior is formed through habituation or conditioning. Secondly, behavior that gets punished will be avoided [11]. So littering behavior is the result of habituation formed by the environment. This happens because the behavior of littering does not get a penalty (for example fined), even the perpetrators actually get a pleasant consequence that is free from garbage. So if you want to reduce littering, the culprit must be fined consistently. Based on this, an environmental approach is needed.

An environmental approach is a way to understand people's behavior. This means that someone behaves in a certain way more because of environmental factors, not because of his own consideration (internal factors). The reason is that Indonesian society has a collective characteristic in which the consideration / presence of others is very dominant in the decision making process [12]. When a person is in a dirty place, he will not care about his own garbage. Dirty places that mean that the surrounding community will allow the behavior of littering and that behavior will not be sanctioned [13]. So the more someone is in a dirty environment, the higher the tendency to litter. This behavior also shows the perception that the party responsible for waste is the government, not the individual [14]. One way to overcome these perceptions is through environmental awareness programs by applying the $3 R$ principle in everyday life. Efforts to care for the environment as a basis for [15]

Based on the description above, the researcher is interested in studying the issue of improving student (santri) care for the living environment in Nurul Huda Islamic boarding school, Depok

\section{RESEARCH METHODS}

In this study, the researchers chose the location of the study at Nurul Huda Islamic Boarding School in Rumbut Village, Pasir Gunung Selatan Cimanggis Village, Depok. The time of this research starts from July 2019 until September 2019. The research method used is descriptive analysis supported by secondary data and literature studies. The approach to analyzing data based on the perspective of national interests, integrative and analysis is multidisciplinary in accordance with the theoretical framework used [16]. Respondents in this study were 80 santri at the Nurul Huda Islamic Boarding School, the instruments were prepared using standard instrument development procedures and their level of validity and reliability can be accounted for [17].

\section{RESULTS AND DISCUSSION}

Increasing santri concern for the environment;

1) Attitudes as a basis for santri concern for the environment
The discussion about the concern of santri in the environment is essentially discussing the behavior displayed by santri towards the environment. As revealed by Fisher, that the basis of behavior is attitude, so before entering in a more detailed behavior analysis the discussion of attitude needs to be raised first. In addition, efforts made to change attitudes have an impact on behavioral change.

The same thing is also stated to measure a person's level of affection for the environment. The sum of the values of each component reflects the level of knowledge and the level of affection for the environment. There are three categories of knowledge and affection for the environment: low, medium and high. The results obtained from a survey involving 80 santri at the Nurul Huda Islamic boarding school, Depok about their attitude to the environment in 2019 can be seen in the following table 1 .

Table 1: Santri Attitudes to the Environment

\begin{tabular}{|l|c|c|c|c|c|c|}
\hline \multirow{2}{*}{ Santri } & \multicolumn{3}{|c|}{ knowledge \% } & \multicolumn{3}{c|}{ affection \% } \\
\cline { 2 - 7 } & low & midle & high & low & midle & high \\
\hline male & 1,3 & 37,9 & 60,8 & 1,1 & 63,5 & 35,4 \\
\hline female & 1.5 & 29,9 & 68,6 & 1,0 & 54,3 & 44,7 \\
\hline
\end{tabular}

The table shows that in general santri at Nurul Huda Islamic boarding school, Depok who have knowledge in the high category are more than those who have affections in the high category. That is, santri at the Nurul Huda Islamic Boarding School in general have extensive knowledge about the environment, but its affection aspects are less touched. The santri know that waste should be sorted according to type before disposal. The aim is to facilitate the process of recycling waste, especially plastics that are difficult to decompose in nature. Even so, the santri were not moved when they saw that plastic garbage had killed the marine biota.

The interesting thing is male and female santri, having knowledge with low category is $1.3 \%$ while female santri are $1.5 \%$ and for high category male santri are $60.8 \%$ and female santri are $68.6 \%$. Thus over $60 \%$ of the santri have knowledge of the environment with a high category. Perhaps this is related to the more santri getting an understanding of the environment from the ustadz/ustazah, so that santri have more knowledge in the high category than the low and moderate ones. For santri attitudes towards the environment with a high category of female santri $44.7 \%$ higher than male santri $35.4 \%$. While this situation is certainly worrying because the environment must continue to be maintained in a continuous and even improved manner, not just left alone.

After the attitude, the next discussion is about real behavior. Because of the attitude as the basis for the formation of behavior, it is expected that santri who behave positively towards waste will also behave positively towards waste. The following are data on real behavior in terms of waste segregation among 80 santri respondents in the Nurul Huda Islamic boarding school, Depok.

The table 2. above shows that there are real differences about the behavior of disposing garbage between male and female santri. Male santri $(63.9 \%)$ tend to turn over their garbage to cleaning staff and then disposed of to 
TPA/TPS, compared to female santri (20.7\%). Waste management which tends to be often done by santri is burned $(54.1 \%)$, while female santri burns only half of it $(24.8 \%)$. Waste accumulation is more done by female santri (3.4\%) than male santri $1.4 \%$ ). female santri (19\%) more often dispose of their garbage in the river/sewer than male santri $(7.3 \%)$. Because there is no more vacant land, the santri who throw garbage in the yard tend to be few and throw it away $(0.3 \%)$ for male santri and $(0.9 \%)$ for female santri. And there are still $(0.5 \%)$ male santri and $(0.7 \%)$ female santri who deliberately throw their trash into the Ciliwung river. Positive behavior towards waste (recycling and composting) does not differ between male and female santri $(1.2 \%)$ for female santri and (1.7\%) for male santri, this is done because it is guided by the ustadz/ustazah, and if there is an event for the activity.

Table 2: Santri's Behavior in Disposing of Trash

\begin{tabular}{|l|l|c|c|}
\hline No. & Garbage removal behavior & Santri Putra \% & Santri Putri \% \\
\hline 1 & Recycle & 0,6 & 0,2 \\
\hline 2 & Made compost/fertilizer & 1,1 & 1 \\
\hline 3 & Transported by officers & 63,9 & 20,7 \\
\hline 4 & Stockpiled & 1,4 & 3,4 \\
\hline 5 & Burned down & 24,8 & 54,1 \\
\hline 6 & Thrown to river / sewerage & 7,3 & 19 \\
\hline 7 & Disposed into the Ciliwung River & 0,5 & 0,7 \\
\hline 8 & Removed to yard & 0,3 & 0,9 \\
\hline & Total & 100 & 100 \\
\hline
\end{tabular}

Analysis of the data for the table above shows that santri tend to surrender their waste management to other parties (garbage officers/cleaning service). This is because the santri tend to be more willing to pay for cleaning workers rather than self-managed. The next interesting thing is that there is no difference in behavior between male and female santri in managing their waste positively (recycling and composting). Even though the slogan I proclaimed "Cleanliness of a part of faith" is associated with a high concern for recycling behavior [18].

As stated above, attitudes towards the environment are the basis for real behaviors or concerns for the environment. From the explanation in the data above, it can be seen that the santri attitude about the environment is not followed by real behavior. One component of attitude is extensive knowledge about the environment, apparently it is not followed by real behavior, namely recycling and making its own waste compost. In general, the santri would instead hand over the waste management to the sanitation officers / offices and then be piled up at the TPA / TPS. Other behaviors that also stand out but are not environmentally friendly are burning trash, and throwing it into sewers.

\section{2) Santri attitudes and behavior about the environment}

Students' attitudes and behaviors are formed because there is a process of modeling from the Islamic teacher (ustadz/ustazah), the statement of Bandura, and it is done continuously so that the santri become accustomed (the theory of behaviorism). It is hoped that the santri attitudes and behavior will also be positive for the environment. The attitude and behavior of santri towards the environment in the Nurul Huda Islamic boarding school, Depok, shows that the two variables tend to be inconsistent in their relationship. This is because external factors that are not conducive to supporting environmental education, among others, santri lose a model figure that can be a role model. This is important to say because the caring behavior of the waste has not been entrenched, so that the existing model figures are also not visible.

The santri are motivated to continue to love the environment with millennial style that is facilitated by innovative activities, so that participation becomes dominant. The milineal style means utilizing the character of millennial generation that is happy with things that are authentic, users of social media, happy to be a product creator and involved in the development of service products, and have a high curiosity, stressed by Taher. In essence, the santri want to be decisive / involved in a policy. This research emphasizes that santri will behave in a pro-environment manner when they participate in the process of making decisions about the environment in Islamic boarding schools.

\section{3) Santri care for the environment}

The santri should be directed to innovative activities about the environment. They will experience directly the management of these activities. This direct experience will strengthen his concern for the environment, rather than just lectures [19]. Pro environment activities that are most suitable for santri are socio-preneurship activities. It is a business that aims to make a profit. The advantage is to solve social problems / make social changes. So this is not personal gain. All activities are designed by someone who is knowledgeable, has strong interests and motivation to solve social problems. His knowledge is used for product / service processing, marketing, and capital. Capital is made on its own, it does not depend on the government or donors. His efforts were carried out in a very disciplined, innovative, and very digital manner. So his efforts are able to create social values that are valued by the community, because they are aimed at solving social problems, such as waste [20]. So the elements of social entrepreneurship are economic activities, innovation, social activities, and come from the participation of santri [21].

\section{CONCLUSION}

Concern for waste in santri at Nurul Huda Islamic Boarding School at a macro level shows that Environmental Education in santri needs to be addressed. The improvement is not only to answer the issues of sustainability, implementation and effectiveness, but also must be able to answer the challenge to condition positive behavior in the environment in accordance with millennial generation. So it can be concluded that the strengthening of pro-environment education in Islamic boarding schools to increase santri concern for the environment, can be done by;

1) Establish attitude as an indicator of behavior, if the attitude object is related to the comfort function. This 
comfort function is related to the principle of rewards and sanctions. People will try to get as many rewards as possible and avoid sanctions. When someone knows (based on his experience) that the object of the attitude will make him comfortable (in return) then the attitude is positive and behavior is also positive. Vice versa, this positive / negative attitude gets stronger when he knows that other people also support him.

2) Applicability of the principle of rewards and sanctions. A person's behavior is more determined by environmental factors, not their own consideration. Our environment has a collective characteristic in which the presence of others is very dominant in the decision making process. In addition we will feel uncomfortable when different from the environment.

3) The relationship between attitudes and behavior about the environment is not consistent. Santri obey the rules because someone is watching him. Based on the theory of behaviorism, the ustadz/ustazah becomes an environmental officer who is authoritative in front of santri. So if you want to change the attitude so that positive behavior occurs, then associate the object of that attitude with positive things and be done consistently. The strategy is by positive publications, involving popular figures who behave positively, implementing regulations on sanctions consistently, there are officers who have integrity, there is certainty of detecting violations of behavior, and the availability of garbage in sufficient quantities and is easily affordable. In this way, people will become accustomed to positive things. The next strategy is to facilitate santri to participate in innovative projects with a waste theme. This method is to prepare them later to become social entrepreneurs. This is important because waste problems are increasingly difficult to be solved conventionally. Millennial generation has the potential to solve waste problems innovatively..

\section{REFERENCES}

[1] Y. Suchyadi and Nurjanah, "Relationship between Principal Supervision in Increasing the Job Satisfaction of Private Junior High School Teachers in East Bogor District," J. Humanit. Soc. Stud., vol. 02, no. 01, pp. 26-29, 2018.

[2] Y. Suchyadi, "Relationship between Work Motivation and Organizational Culture in Enhancing Professional Attitudes of Pakuan University Lecturers," J. Humanit. Soc. Stud., vol. 01, no. 01, pp. 41-45, 2017.

[3] R. Pertiwi and Y. Suchyadi, "Implementasi Program Pendidikan Karakter Di Sekolah Dasar Negeri Lawanggintung 01 Kota Bogor," J. Pendidik. Pengajaran Guru Sekol. Dasar (JPPGuseda ), vol. 02, pp. 41-46, 2019.

[4] Surip, Syarbani \& Rahman, 2015.Pancasila Dalam Makna dan Aktualisasi. Yogyakarta:CV. Andi Offset.
[5] BPS,2013.Indikator perilaku Peduli Lingkungan Hidup, Jakarta: Biro Pusat Statistik.

[6] S. Setiarani and Y. Suchyadi, "Pola Asuh Orang Tua Terhadap Anak Tuna Netra Berprestasi," J. Pendidik. Pengajaran Guru Sekol. Dasar, vol. 01, no. 01, pp. 15-18, 2018.

[7] Fisher, 1982. Social Psychology: An Applied. New York: St.Martin's Press.

[8] Koran Jakarta, 2018.Generasi Muda Berperan Penting Perangi Sampah. Koran Jakarta.com.22 Januari. Retrieved on Aug. 16.2018

[9] Bandura A. 1986. Social Foundations of Thought and Action: A Social Cognitive Theory. New Jersey: Prentice-Hall, Inc.

[10] Y. Suchyadi, Y. Ambarsari, and E. Sukmanasa, "Analysis of Social Interaction of Mentally Retarded Children," J. Humanit. Soc. Stud., vol. 02, no. 02, pp. 17-21, 2018.

[11] Tondok, 2008. Menyampah, dari Perspektif Psikologi. Harian Surabaya Post. 20 Juli.

[12] Trandis, 2002.Motivation to Work in Cross-Culture Perspective. In J.M.Brett \& F. Drasgow (Eds.) The Psychology of Work. London: Lawrence Erlbaum Associates, Publishers. Pp.101-117.

[13] Kolodko, Read \& Taj. 2016. Using Behavioral Insight to Reduce Littering in the UK. Britain: Clean Up.

[14] Robinson, 1975. Socil and Environmental Influences on Littering Behavior. Dissertation. Georgia Institute of Technology.

[15] Sri Rahayu Pudjiastuti, Mengantisipasi Dampak Bencana Alam, Jurnal Ilmu Pendidikan (JIP) STKIP Kusuma Negara. Volume 10. Issue 2 Pages 14.

[16] Sri Rahayu Pudjiastuti, Metodologi Penelitian Pendidikan (Jakarta : STKIP Kusuma Negara, 2004), h. 15

[17] Sri Rahayu Pudjiastuti, Sri Rumiati. Development of the PKn Learning Attitude Assesment Model in Foreign Political Culture and Results of PKn Learning from Students of Depok City Vocational School (SMK Semesta Cimanggis). JhSS Journal of Humanities and Social Studies, e-ISSN:2598-120X | p-ISSN:2598-117X. Sinta-3. Vol. 3, No.1. 2019.

[18] Crociata, Agovino \& Sacco, 2015. Recycling Waste: Does Culture Matter? Journal of Behavioral and Experimental Econimics. 55.

[19] Kollmuss \& Agyman, 2002. Mind the Gap: Why do People act Environmentally and what are the Barriers to pro- environmental Behavior? Environmental Education Research. 8(3).238-260.

[20] Abu Salfian, 2012, Social Entrepreneurship: Definition and Boudaries Technology Innovation Management Review. Fepruary, p.22-27.

[21] Sofia, 2015, Konstruksi Model Kewirausahaan Sosial sebagai gagasan inovasi sosial bagi pembangunan perekonomian. Jurnal Universitas Pembangunan Jaya, 2(2). Maret. 2-23. 